\title{
Enzymatic Inhibition Studies of Selected Flavonoids and Chemosystematic Significance of Polymethoxylated Flavonoids and Quinoline Alkaloids in Neoraputia (Rutaceae)
}

\author{
Valéria R. de S. Moraes ${ }^{a, b}$, Daniela M. Tomazela ${ }^{a}$, Ricardo J. Ferracin ${ }^{a}$, Cleverson F. Garcia ${ }^{a}$, \\ Míriam Sannomiya ${ }^{b}$, M. del Pilar C. Soriano ${ }^{b}$, M. Fátima das G. F. da Silva ${ }^{*, a}$, Paulo C. Vieira ${ }^{a}$, \\ João B. Fernandes ${ }^{a}, E_{\text {Edson Rodrigues Filho }}{ }^{\prime}$, Eva G. Magalhães ${ }^{b}$, Aderbal F. Magalhães ${ }^{b}$, \\ Eli F. Pimenta ${ }^{c}$, Dulce H. F. de Souza ${ }^{c}$ and Glaucius Oliva ${ }^{c}$ \\ ${ }^{a}$ Departamento de Química, Universidade Federal de São Carlos, CP 676, 13565-905 São Carlos -SP, Brazil \\ ${ }^{b}$ Universidade Estadual de Campinas, Instituto de Química, CP 6154, 130843-971 Campinas - SP, Brazil \\ ${ }^{c}$ Instituto de Física de São Carlos, Universidade de São Paulo, CP 369, 13560-970 São Carlos - SP, Brazil
}

\begin{abstract}
Nosso interesse quimiotaxonômico sobre Neoraputia nos estimulou a examinar $N$. paraensis, visando a busca de alcalóides. As frações foram monitoradas via RMN ${ }^{1} \mathrm{H}$ e ESI-EM/EM e foram analisadas somente aquelas cujos espectros apresentavam características de alcalóides do ácido antranílico e flavonóides não isolados anteriormente. Foram isolados do caule os alcalóides flindersina, skimmianina, 8-metoxiflindersina e dictamnina; das folhas os flavonóides 3',4',7,8-tetrametoxi-5,6(2",2"-dimetilpirano)-flavona, 3',4',5,7,8-pentametoxiflavona, 5-hidroxi-3',4',6,7-tetrametoxiflavona, 3',4'-metilenodioxi-5,6,7-trimetoxiflavona e 5-hidroxi-3',4'-metilenodioxi-6,7-dimetoxiflavona,. Os alcalóides do ácido antranílico não foram encontrados em dez anos.

Vários flavonóides isolados de N. paraensis, N. magnifica, Murraya paniculata, enxerto de Citrus sinensis (Rutaceae) e Lonchocarpus montanus (Leguminosae) foram testados frente a gliceraldeído-3-fosfato desidrogenase de Trypanosoma cruzi, visando verificar seus potenciais em inibir a atividade da enzima. Os flavonóides polimetoxilados e um isoflavonóide foram os mais ativos.
\end{abstract}

Our taxonomic interest in the Neoraputia stimulated an investigation of $N$. paraensis searching for alkaloids. Fractions were monitored by ${ }^{1} \mathrm{H}$ NMR and ESI-MS/MS and only those which showed features of anthranilate alkaloids and flavonoids absent in the previous investigations were examined. Stems afforded the alkaloids flindersine, skimmianine, 8-methoxyflindersine and dictamnine; leaves yielded 3',4',7,8-tetramethoxy-5,6-(2",2"-dimethylpyrano)-flavone, 3',4',5,7,8pentamethoxyflavone, 5-hydroxy-3',4',6,7-tetramethoxyflavone, 3',4'-methylenedioxy-5,6,7trimethoxyflavone and 5-hydroxy-3',4'-methylenedioxy-6,7-dimethoxyflavone. The alkaloids have remained undiscovered for 10 years.

A number of flavonoids isolated from N. paraensis, N. magnifica, Murraya paniculata, Citrus sinensis graft (Rutaceae), Lonchocarpus montanus (Leguminosae) were evaluated for their ability to inhibit the enzymatic activity of the protein glyceraldehyde-3-phosphate dehydrogenase from Trypanosoma cruzi. Highly oxygenated flavones and isoflavone were the most actives.

Keywords: Rutaceae, Leguminosae, Neoraputia, Murraya, Citrus, Lonchocarpus, Trypanosoma cruzi, alkaloid, flavonoids, chemosystematic

\section{Introduction}

Neoraputia species were originally described by Engler as species of Raputia Aublet. Emmerich later proposed the new genus Neoraputia Emmerich to accommodate six species, four of them from Raputia and two new ones. These

\footnotetext{
* e-mail: dmfs@power.ufscar.br
}

two genera are assigned to the tribe Cusparieae. ${ }^{1}$ Previous investigations of Neoraputia reported the presence of eleven polymethoxylated flavonoids, six flavones, three 5,6-(2",2"dimethylpyrano)-flavones, one 6,7-(2",2"-dimethylpyrano)flavone and one flavanone from $N$. alba (Engler) Emmerich;,2,3 five polymethoxylated flavones and two flavanones, 2'hydroxy-3,4,4',5,6'-pentamethoxychalcone, three 5',6'-(2",2"dimethylpyrano)-polymethoxylated chalcones from $N$. 
magnifica var. magnifica (Engler) Emmerich; ${ }^{4,5}$ ten polymethoxylated flavonoids, six flavones, three 6,7-(2",2"dimethylpyrano)-flavones and one 6-(3"-hydroxy,3"'-methyltrans-but-1"-enyl)-flavone from $N$. paraensis ${ }^{6,7}$ All phytochemical studies on Neoraputia genus have been undertaken in our laboratory and by Arruda et al. ${ }^{6,7}$, and isolation procedures used in these studies should have revealed rutaceous alkaloids, coumarins and limonoids if they had been present. If Emmerich'proposal is correct, that Neoraputia is a Cusparieae member, then this genus can be regarded as a potential source of anthranilate alkaloids. Thus, it would be not surprising if anthranilate alkaloids had remained undiscovered in the Neoraputia because of their low concentrations or due to seasonal variations in the chemical composition of its species. Therefore, it is premature to use the absence of other classes of compounds as an argument to remove Neoraputia to the Citroideae, which produces a considerable number of highly oxygenated flavones. ${ }^{4,8}$ Clearly much more detailed phytochemical investigations of Neoraputia species will be essential for a better understanding of its chemotaxonomic position in the Rutaceae. In order to establish this we have now undertaken a further investigation of $N$. paraensis.

Chagas' disease, caused by the protozoan Trypanosoma cruzi, is estimated to affect some 16-18 million people, mostly from South and Central America, where 25\% of the total population is at risk (World Health Organisation). Control of the insect vector (Triatoma infestans) in endemic areas has led to the virtual elimination of transmission by insect bites, and, as a consequence, blood transfusion and congenital transmission are currently the major causes for the spread of the disease. Besides low efficacy, the drugs currently available, nifurtimox and benzonidazole, have strong side effects. ${ }^{9}$ The bloodstream form of the parasite Trypanosoma cruzi has no functional tricarboxylic acid cycle, and it is highly dependent on glycolysis for ATP production. ${ }^{9}$ This great dependence on glycolysis as a source of energy makes the glycolytic enzymes attractive targets for trypanocidal drug design. Thus, the three dimensional structure of the enzyme was determined. ${ }^{9}$ Glyceraldehyde3-Phosphate Dehydrogenase (GAPDH) catalyses the oxidative phosphorylation of glyceraldehyde-3-phosphate to 1,3-bisphosphoglycerate. Glycosomal GAPDH shows potential target sites with significant differences compared with the homologous human enzyme, and inhibitors have been designed, synthesised, obtained from natural sources, and tested. ${ }^{9}$

Highly oxygenated flavones from Neoraputia magnifica have shown to be the most actives as glyceraldehyde-3-phosphate dehydrogenase-inhibitor. ${ }^{5}$ These data stimulated an investigation of other flavonoids.
Thus, in order to find potential lead compounds, flavonoids isolated from Neoraputia paraensis, N. magnifica, Murraya paniculata, Citrus sinensis grafted on C. limon (Rutaceae), Lonchocarpus montanus (Leguminosae) were assayed and evaluated by interaction with the enzyme GAPDH from Trypanosoma cruzi.

\section{Results and Discussion}

Our taxonomic interest in the Neoraputia stimulated an investigation of the extracts from stems and leaves of $N$. paraensis searching for alkaloids, which were detected by the characteristic color with Dragendorff's reagent on TLC plates. Fractions were monitored by ${ }^{1} \mathrm{H}$ NMR (200 $\mathrm{MHz}$ ) and ESI-MS/MS and were examined only those which showed features of anthranilate alkaloids and flavonoids absent in the previous investigations.

The dichloromethane extract from stems afforded only the alkaloid flindersine (1). ${ }^{10}$ The HSQC and HMBC experiments on flindersine, permitted minor corrections to previous ${ }^{13} \mathrm{C}$ NMR assignments. ${ }^{10}$ Table 1 shows that the signals for $\mathrm{C}-3$ and $\mathrm{C}-10$ to $\mathrm{C}-12$ were reassigned. The observed correlations between the methine hydrogen signal at $\delta 6.77$ and the ${ }^{13} \mathrm{C}$ signals at $\delta 162.5,157.3$ and 79.1 led to their assignments as C-2, C-4, C-13, respectively. The upfield methine hydrogen signal at $\delta 5.56$ showed correlation with the ${ }^{13} \mathrm{C}$ signals at $\delta 105.8,79.1$ and 26.3 permitting the assignment of these signals to C-3, C-13 and $\mathrm{C}-14 / 15$, respectively. The signals at $\delta 6.77$ and 5.56 were then assigned to $\mathrm{H}-11$ and $\mathrm{H}-12$, respectively.

The methanolic extract from stems afforded skimmianine, ${ }^{11}$ 8-methoxyflindersine $\quad(2)^{12}$ and dictamnine. ${ }^{13,14}$ As no carbon shifts of $\mathbf{2}$ could be found in the literature, these data are listed in Table 1. Complete and unambiguous ${ }^{13} \mathrm{C}$ NMR assignments for $\mathbf{2}$ were made using the HSQC and HMBC techniques and using $\mathbf{1}$ and haplophytin $\mathrm{A}(\mathbf{3})^{15}$ as a models. The methine hydrogen signal at $\delta 6.71$ showed correlation with the ${ }^{13} \mathrm{C}$ signals at $\delta$ 157.1 permitting the assignment of these signals to $\mathrm{H}-11$ and C-4. Thus, in compound $\mathbf{1}$ and $\mathbf{2}, \mathrm{H}-11$ is more deshielded than $\mathrm{H}-12$. However, in model 3 the presence of the methoxyl at $\mathrm{C}-5$ caused downfield shift of the usual range for 4,O-3-chromene quinolines, resulting in the $\mathrm{H}-12$ being more deshielded than $\mathrm{H}-11$. The methoxyl at C-5 also induces effects on $\mathrm{C}-10$ and $\mathrm{C}-3$, exhibiting upfield displacement for C-10 and downfield displacement for C-3. These data were also confirmed by HMBC experiments. ${ }^{15}$

The $n$-hexane extract of the leaves yielded $3^{\prime}, 4^{\prime}, 7,8$ tetramethoxy-5,6-(2",2"-dimethylpyrano)-flavone ${ }^{3}$ (4) which has not been recorded from $N$. paraensis. The dichloromethane extract from leaves gave four flavonoids, 
Table 1. ${ }^{1} \mathrm{H}$ and ${ }^{13} \mathrm{C}$ NMR chemical shifts for alkaloids $\mathbf{1}, 2$ and model 3

\begin{tabular}{|c|c|c|c|c|c|c|c|c|}
\hline \multirow[b]{2}{*}{ Atom } & \multicolumn{3}{|c|}{$\mathbf{1}^{\mathrm{a}}$} & \multicolumn{3}{|c|}{$2^{\mathrm{a}}$} & \multicolumn{2}{|c|}{$3^{\mathrm{a}}$} \\
\hline & $\delta_{\mathrm{C}}$ & $\underset{J}{\delta_{\mathrm{H}} \mathrm{m}}$ & $\begin{array}{l}\text { HMBC } \\
{ }^{1} \mathrm{H} \rightarrow{ }^{13} \mathrm{C}\end{array}$ & $\delta_{\mathrm{C}}$ & $\underset{J}{\delta_{\mathrm{H}} \mathrm{m}}$ & $\begin{array}{l}\mathrm{HMBC} \\
{ }^{1} \mathrm{H} \rightarrow{ }^{13} \mathrm{C}\end{array}$ & $\delta_{\mathrm{C}}$ & $\underset{J}{\delta_{\mathrm{H}} \mathrm{m}}$ \\
\hline 2 & 162.5 & & & 160.5 & & & 162.4 & \\
\hline 3 & 105.8 & & & 106.2 & & & 115.7 & \\
\hline 4 & 157.3 & & & 157.1 & & & 156.0 & \\
\hline 5 & 122.6 & $\begin{array}{l}7.89 \mathrm{~d} \\
(7.5)\end{array}$ & $\begin{array}{l}157.3 \\
137.2 \\
130.8\end{array}$ & & 114.6 & $\begin{array}{c}7.46 \mathrm{dd} \\
(8.0,1.0)\end{array}$ & $\begin{array}{l}110.3 \\
127.9\end{array}$ & 155.0 \\
\hline 6 & 122.2 & $\begin{array}{l}7.19 \mathrm{t} \\
(7.5)\end{array}$ & 115.4 & 121.7 & $\begin{array}{l}7.10 \mathrm{t} \\
(8.0)\end{array}$ & $\begin{array}{l}115.7 \\
145.5\end{array}$ & 103.5 & \\
\hline 7 & 130.8 & $\begin{array}{l}7.48 \mathrm{t} \\
(7.5)\end{array}$ & $\begin{array}{l}137.2 \\
122.6\end{array}$ & 110.3 & $\begin{array}{c}6.94 \mathrm{dd} \\
(8.0,1.0)\end{array}$ & $\begin{array}{l}114.6 \\
127.9\end{array}$ & 120.5 & \\
\hline 8 & 115.9 & $\begin{array}{l}7.33 \mathrm{~d} \\
(7.5)\end{array}$ & $\begin{array}{l}122.2 \\
115.4\end{array}$ & 145.5 & & & 117.4 & \\
\hline 9 & 137.2 & & & 127.9 & & & 132.9 & \\
\hline 10 & 115.4 & & & 115.7 & & & 106.5 & \\
\hline 11 & 117.2 & $\begin{array}{l}6.77 \mathrm{~d} \\
(9.9)\end{array}$ & $\begin{array}{r}79.1 \\
157.3 \\
162.5\end{array}$ & 117.3 & $\begin{array}{l}6.71 \mathrm{~d} \\
(9.9)\end{array}$ & $\begin{array}{r}79.1 \\
157.1\end{array}$ & 126.2 & $\begin{array}{l}5.54 \mathrm{~d} \\
(9.9)\end{array}$ \\
\hline 12 & 126.2 & $\begin{array}{l}5.56 \mathrm{~d} \\
(9.9)\end{array}$ & $\begin{array}{r}26.3 \\
79.1 \\
105.8\end{array}$ & 126.2 & $\begin{array}{l}5.52 \mathrm{~d} \\
(9.9)\end{array}$ & $\begin{array}{r}79.1 \\
106.2\end{array}$ & 117.5 & $\begin{array}{l}6.76 \mathrm{~d} \\
(9.9)\end{array}$ \\
\hline 13 & 79.1 & & & 79.1 & & & 79.0 & \\
\hline $14 / 15$ & 26.3 & $1.54 \mathrm{~s}$ & & 28.1 & $1.52 \mathrm{~s}$ & & 28.0 & \\
\hline $\mathrm{N}-\mathrm{H}$ & - & $11.5 \mathrm{~s}$ & & - & $8.87 \mathrm{~s}$ & & & \\
\hline $\mathrm{OMe}$ & - & - & & 56.0 & $3.95 \mathrm{~s}$ & & 55.7 & \\
\hline
\end{tabular}

a (in $\mathrm{CDCl}_{3}$ ).

3',4',5,7,8-pentamethoxyflavone ${ }^{16}(\mathbf{5})$, 5-hydroxy-3',4',6,7tetramethoxyflavone ${ }^{17}(\mathbf{6}), 3^{\prime}, 4^{\prime}$-'methylenedioxy-5,6,7trimethoxyflavone ${ }^{5}(7)$ and $\mathbf{8}$, which are reported for the first time from $N$. paraensis, while the latter appears to be new.

The flavone 8 exhibited a B-ring spin system in the ${ }^{1} \mathrm{H}$ NMR spectrum (Table 2) for 3',4'-substitution $(\delta 7.33, \mathrm{~d}, J$ $1.8 \mathrm{~Hz}, \mathrm{H}-2 ' ; \delta 6.93, \mathrm{~d}, J 8.2 \mathrm{~Hz}, \mathrm{H}-5 ' ; \delta 7.46$, dd, $J 8.2$ and $\left.1.8 \mathrm{~Hz}, \mathrm{H}-6^{\prime}\right)$. This spectrum also showed signals for two methoxy groups $(\delta 3.97, \mathrm{~s} ; 3.92, \mathrm{~s})$, one methylenedioxy group $(\delta 6.08, \mathrm{~s}, 2 \mathrm{H})$, one hydroxyl group at $\delta 12.73(1 \mathrm{H}$, s, OH-5) and two singlets at $\delta 6.54(\mathrm{H}-8)$ and $6.55(\mathrm{H}-3)$ indicating the A-ring to be 5,6,7- or 5,7,8-trisubstituted and a flavone nucleus. The retro-Diels-Alder (RDA) ${ }^{17}$ fragments in ESI-MS/MS of this flavone gives a good indication of the substitution patterns of the A- and Brings. Thus, a combination of ${ }^{1} \mathrm{H}$ NMR data and the fragment ions at $\mathrm{m} / \mathrm{z} 146(30 \%)$ and 181 (RDA-Me, 100\%) fully supported the presence of 3',4'-methylenedioxy substituent in the B-ring and 5-hydroxy-6,7-dimethoxy or 5-hydroxy-7,8-dimethoxy system in the A-ring. A comparison of ${ }^{13} \mathrm{C}$ chemical shifts of 5-OH-7,8- and 5-OH6,7-dimethoxyflavone and 5-OH-3,7,8- and 5-OH-3,6,7trimethoxyflavonol indicated that C-6 methine ( $c a . \delta 96)$ resonates at lowerfield than $\mathrm{C}-8$ methine $(c a . \delta 91) .{ }^{18}$ Thus,
Table 2. ${ }^{1} \mathrm{H}$ and ${ }^{13} \mathrm{C}$ NMR chemical shifts for flavone 8 and models $\mathbf{9}$ and $\mathbf{1 0}$

\begin{tabular}{|c|c|c|c|c|}
\hline \multirow{2}{*}{ Atom } & \multicolumn{2}{|c|}{$8^{\mathrm{a}}$} & \multirow{2}{*}{$\frac{\mathbf{9}^{\mathbf{a}, 18}}{\delta_{\mathrm{C}}}$} & \multirow{2}{*}{$\frac{10^{\mathrm{b}, 5}}{\delta_{\mathrm{C}}}$} \\
\hline & $\delta_{\mathrm{H}} \mathrm{m}(J)$ & $\delta_{\mathrm{C}}$ & & \\
\hline 2 & & 163.7 & 163.9 & 160.2 \\
\hline 3 & $6.55 \mathrm{~s}$ & 104.7 & 105.4 & 108.7 \\
\hline 4 & & 182.7 & 182.6 & 176.6 \\
\hline 5 & & 153.2 & 152.9 & 161.3 \\
\hline 6 & & 132.8 & 132.6 & 96.8 \\
\hline 7 & & 158.8 & 158.8 & 164.4 \\
\hline 8 & $6.54 \mathrm{~s}$ & 90.6 & 90.6 & 93.7 \\
\hline 9 & & 153.1 & 153.2 & 160.1 \\
\hline 10 & & 106.3 & 106.2 & 109.7 \\
\hline 1 , & & 125.4 & 131.1 & 126.0 \\
\hline 2 ' & $\begin{array}{l}7.33 \mathrm{~d} \\
(1.8)\end{array}$ & 106.3 & 126.1 & 106.6 \\
\hline 3 ' & & 148.6 & 129.0 & 148.9 \\
\hline $4^{\prime}$ & & 150.9 & 131.8 & 150.6 \\
\hline 5 , & $\begin{array}{l}6.93 \mathrm{~d} \\
(8.2)\end{array}$ & 108.8 & 129.0 & 108.9 \\
\hline $6^{\prime}$ & $\begin{array}{r}7.46 \mathrm{dd} \\
(8.2,1.8)\end{array}$ & 121.5 & 126.1 & 121.3 \\
\hline $\mathrm{OMe}$ & $3.97 \mathrm{~s}$ & 60.9 & & 55.9 \\
\hline $\mathrm{OMe}$ & $3.92 \mathrm{~s}$ & 56.4 & & 56.2 \\
\hline $\mathrm{OH}$ & $12.73 \mathrm{~s}$ & & & \\
\hline $\mathrm{OCH}_{2} \mathrm{O}$ & $6.08 \mathrm{~s}$ & 102.1 & & 102.5 \\
\hline
\end{tabular}

a (in $\mathrm{CDCl}_{3}$ ); ${ }^{\text {b }}$ (in pyridine-d $_{6}$. 
the correct A-ring was decided on the basis of ${ }^{13} \mathrm{C} \mathrm{NMR}$ spectrum (Table 2) which showed signal at $\delta 90.6$ for $\mathrm{C}-8$, so placing the methoxyl substituents at C-7 and C-6. From these data 8 was characterised as 5-hydroxy-3',4'methylenedioxy-6,7-dimethoxyflavone. The structural assignment was also supported by comparison of the ${ }^{13} \mathrm{C}$ NMR spectrum with those of 5-hydroxy-6,7-dimethoxyflavone $(9)^{18}$ and 3',4'-methylenedioxy-5,7-dimethoxyflavone $(\mathbf{1 0}){ }^{5}$

Preliminary work was firstly undertaken on specimens collected in Paragominas, state of Pará, north of Brazil, in February 1991.6,7 The present results obtained from specimens originating from Uruçuca, Bahia (February 1993), showed that there was no difference in the flavonoids between the two collections. However, alkaloids were obtained only from plants of northeast region (Bahia), which is characterized by drought summer, compared to rainy summer in the northern (Pará). In contrast, Neoraputia alba and N. magnifica collected in Espirito Santo, near northeast of Brazil, had only high concentration of flavonoids. Thus, geographic-variation do not seem to be an important environmental factor. The low concentration of anthranilate alkaloids is likely to be responsible for the alkaloids have remained undiscovered for 10 years. All alkaloids were obtained in very small amounts (1-3 mg), only flindersine (1) was present in substantial amounts $(10 \mathrm{mg})$.

In a previous paper concerning the chemical systematics of Cusparieae, which Neoraputia has been assigned, ${ }^{8}$ the importance of coumarins and anthranilate alkaloids was highlighted. This study brings into focus polyoxygenated flavonoids as another taxonomically useful chemical marker in this group. Many chemists are perhaps interested in alkaloids, coumarins and limonoids from Rutaceae and will rarely identify all of the potentially systematic important classes of compounds presents in the plant, e.g. flavonoids, since they are generally found in most if not all angiosperm plants. Thus, clearly rutaceous flavonoids deserve more attention than they have received so far.

A number of flavonoids isolated from Neoraputia paraensis, N. magnifica, ${ }^{4,5}$ Murraya paniculata, ${ }^{19}$ Citrus sinensis grafted on C. limon $^{20}$ (Rutaceae), Lonchocarpus montanus $^{21}$ (Leguminosae) were evaluated for their ability to inhibit the enzymatic activity of the protein glycosomal GAPDH from Trypanosoma cruzi. The positive results are summarized at Table 3 and the occurrence of flavonoids evaluated at Table 4. GAPDH activity was only inhibited by $65 \%$ when 2 '-hydroxy-3,4,4',5-tetramethoxy-5',6'-(2",2"dimethylpyrano)chalcone (11) was added to the assay system at a concentration of $100 \mu \mathrm{g} \mathrm{mL}^{-1}$, suggesting that chalcones act as weak inhibitors. The flavones 3',4',5',5,7pentamethoxyflavone (12), 3',4',5,6,7-pentamethoxyflavone
Table 3. Effect of flavonoids ${ }^{\mathrm{a}}$ on TcGAPDH activity

\begin{tabular}{|c|c|c|c|c|}
\hline Compound & $\begin{array}{l}\text { Concentration } \\
\left(\mu \mathrm{g} \mathrm{mL}^{-1}\right)\end{array}$ & Absorbance & $\begin{array}{l}\text { Specific } \\
\text { activity } \\
\left(\mathrm{U} \mathrm{mg}^{-1}\right)\end{array}$ & $\begin{array}{c}\% \text { Inhibitory } \\
\text { activity }\end{array}$ \\
\hline 4 & 35 & 0.249 & 14.69 & 68 \\
\hline Control & 35 & 0.773 & 45.61 & \\
\hline 5 & 50 & 0.312 & 22.38 & 45 \\
\hline Control & 50 & 0.568 & 40.62 & \\
\hline \multirow[t]{2}{*}{7} & 50 & 0.606 & 43.28 & 0 \\
\hline & 100 & 0.395 & 28.18 & 36 \\
\hline \multirow[t]{2}{*}{ Control } & 50 & 0.594 & 42.42 & \\
\hline & 100 & 0.621 & 44.37 & \\
\hline \multirow[t]{2}{*}{10} & 50 & 0.546 & 39.04 & 8 \\
\hline & 100 & 0.465 & 33.20 & 26 \\
\hline \multirow[t]{2}{*}{ Control } & 50 & 0.594 & 42.42 & \\
\hline & 100 & 0.621 & 44.37 & \\
\hline \multirow[t]{2}{*}{11} & 50 & 0.638 & 45.62 & 0 \\
\hline & 100 & 0.215 & 15.33 & 65 \\
\hline \multirow[t]{2}{*}{ Control } & 50 & 0.594 & 42.42 & \\
\hline & 100 & 0.621 & 44.37 & \\
\hline \multirow[t]{3}{*}{$12^{5}$} & 30 & 0.345 & 24.65 & 46 \\
\hline & 50 & 0.136 & 9.72 & 80 \\
\hline & 100 & 0.009 & 0.64 & 99 \\
\hline \multirow[t]{3}{*}{ Control } & 30 & 0.641 & 45.80 & \\
\hline & 50 & 0.670 & 47.87 & \\
\hline & 100 & 0.560 & 40.01 & \\
\hline 13 & 100 & 0.000 & 0.00 & 100 \\
\hline Control & 100 & 0.621 & 44.37 & \\
\hline \multirow[t]{2}{*}{14} & 50 & 0.033 & 2.38 & 94 \\
\hline & 100 & 0.000 & 0.00 & 100 \\
\hline \multirow[t]{2}{*}{ Control } & 50 & 0.594 & 42.42 & \\
\hline & 100 & 0.621 & 44.37 & \\
\hline \multirow[t]{2}{*}{15} & 50 & 0.083 & 5.96 & 86 \\
\hline & 100 & 0.000 & 0.00 & 100 \\
\hline \multirow[t]{2}{*}{ Control } & 50 & 0.594 & 42.42 & \\
\hline & 100 & 0.652 & 46.56 & \\
\hline \multirow[t]{2}{*}{16} & 50 & 0.371 & 26.52 & 38 \\
\hline & 100 & 0.078 & 5.57 & 88 \\
\hline \multirow[t]{2}{*}{ Control } & 50 & 0.594 & 42.42 & \\
\hline & 100 & 0.652 & 46.56 & \\
\hline \multirow[t]{2}{*}{17} & 50 & 0.055 & 3.92 & 91 \\
\hline & 100 & 0.000 & 0.00 & 100 \\
\hline \multirow[t]{2}{*}{ Control } & 50 & 0.594 & 42.42 & \\
\hline & 100 & 0.652 & 46.56 & \\
\hline \multirow[t]{2}{*}{18} & 50 & 0.273 & 19.51 & 54 \\
\hline & 100 & 0.027 & 2.03 & 96 \\
\hline \multirow{2}{*}{ Control } & 50 & 0.594 & 42.42 & \\
\hline & 100 & 0.652 & 46.56 & \\
\hline
\end{tabular}

a Occurrence of flavonoids in genera of Rutaceae and Leguminosae see Table 4; Control: $50 \mathrm{mmol} \mathrm{L}{ }^{-1}$ tris- $\mathrm{HCl} \mathrm{pH} 8.6$ buffer, $1 \mathrm{mmol} \mathrm{L}^{-1}$ EDTA, $1 \mathrm{mmol} \mathrm{L} \mathrm{L}^{-1} \beta$-mercapto-ethanol, $30 \mathrm{mmol} \mathrm{L}{ }^{-1} \mathrm{Na}_{2} \mathrm{HAsO}_{4}$, $2.5 \mathrm{mmol} \mathrm{L}^{-1} \mathrm{NAD}^{+}, 0.3 \mathrm{mmol} \mathrm{L}{ }^{-1}$ glyceraldehyde-3-phosphate, 4-9 $\mu \mathrm{g}$ protein and $10 \%$ DMSO, in a total volume of $1000 \mu \mathrm{L}$; Positive standard: coumarin chalepin, concentration $\left(\mu \mathrm{g} \mathrm{mL}^{-1}\right)=30$, $\left(\mathrm{U} \mathrm{mg}^{-1}\right)=3.50, \%$ inhibitory activity $=75, \mathrm{IC}_{50}=64 \mu \mathrm{mol} \mathrm{L}^{-1} \cdot 22$

(13), 4',5,6,7,8-pentamethoxyflavone (14) and flavonol 3',4',5',3,5,6,7-heptamethoxyflavonol (15) completely inhibited the enzymatic activity (by 99-100\%) at $100 \mu \mathrm{g} \mathrm{mL}^{-1}$. The activity does not appear to be affected by the introduction of the 3-OMe substituent into the flavone 
Table 4. Occurrence of flavonoids evaluated on TcGAPDH activity

\begin{tabular}{clc}
\hline Compound & Family/Species & References \\
\hline \multirow{2}{*}{4} & Rutaceae & \\
& Neoraputia alba & 3 \\
$\mathbf{5}$ & N. paraensis & $\mathrm{a}$ \\
& N. alba & 3 \\
$\mathbf{7}$ & N. paraensis & $\mathrm{a}$ \\
& N. magnifica & 5 \\
$\mathbf{1 0}$ & N. paraensis & $\mathrm{a}$ \\
$\mathbf{1 1}$ & N. magnifica & 5 \\
$\mathbf{1 2}$ & N. magnifica & 4,5 \\
& N. magnifica & 3 \\
$\mathbf{1 3}$ & N. paraensis & 5 \\
$\mathbf{1 4}$ & Citrus sinensis grafted on C. limon & 6,7 \\
$\mathbf{1 5}$ & C. sinensis grafted on C. limon & 20 \\
$\mathbf{1 6}$ & Murraya paniculata & 20 \\
& M. paniculata & 19 \\
\multirow{2}{*}{$\mathbf{1 7}$} & Leguminosae & 19 \\
$\mathbf{1 8}$ & Lonchocarpus montanus & \\
& L. montanus & 21 \\
\hline
\end{tabular}

${ }^{a}$ Reported for the first time from this species. skeleton. However, the activity of $3^{\prime}, 4^{\prime}, 5^{\prime}, 3,5,7,8$ heptamethoxyflavonol (16) was comparable to that of $\mathbf{1 5}$ but, reducing the enzymatic activity by $88 \%$ at $100 \mu \mathrm{g} \mathrm{mL}^{-1}$. This finding shows that the activity varies with the position of methoxyl group. The higher activity of 12, 13, 14 and 15 could possibly be attributed to a greater symmetry of electron density of the molecules. Flavones 3',4'-methylenedioxy5,7-dimethoxyflavone (10) and 3',4'-methylenedioxy-5,6,7trimethoxyflavone (7) do not display significant GAPDH activity (26\% and $36 \%$, respectively) showing that $3{ }^{\prime}, 4^{\prime}-$ methylenedioxy reduce drastically inhibitory activity. Differences between polyoxygenated flavones and isoflavone afrormosine (17) inhibitory activities are not significant, indicating that the presence of many methoxy groups in isoflavones are not a requirement for activity. However, isoflavone possess 3-phenylchromone skeleton and it may be incorrect to compare it with the other flavones tested. GAPDH activity was also inhibited by $96 \%$ when auronol derriobtusone $\mathrm{A}(\mathbf{1 8})$ was added to the assay system at a concentration of $100 \mu \mathrm{g} \mathrm{mL}^{-1}$.<smiles>[R]c1ccc([R])c2c3c(c(=O)[nH]c12)C=CC(C)(C)O3</smiles>

$\begin{array}{lll} & \mathrm{R} & \mathrm{R}^{1} \\ \text { 1: } & \mathrm{H} & \mathrm{H} \\ \text { 2: } & \mathrm{H} & \mathrm{OMe} \\ \text { 3: } & \mathrm{OMe} & \mathrm{H}\end{array}$<smiles>[R]c1cc(-c2oc3c([R])c([R])c([R])c([R])c3c(=O)c2[R])cc([R])c1[R]</smiles><smiles>COc1ccc(-c2cc(=O)c3c4c(c(C(=O)O)c(OC)c3o2)C=CC(C)(C)O4)cc1OC</smiles>

$\begin{array}{llllllll}\mathrm{R} & \mathrm{R}^{1} & \mathrm{R}^{2} & \mathrm{R}^{3} & \mathrm{R}^{4} & \mathrm{R}^{5} & \mathrm{R}^{6} & \mathrm{R}^{7}\end{array}$

5: $\mathrm{H} \quad \mathrm{OMe} \mathrm{OMe} \mathrm{H}$ OMe $\mathrm{H} \quad \mathrm{OMe} \quad \mathrm{OMe}$

6: $\mathrm{H}$ OMe $\mathrm{OMe} \mathrm{H}$ OH $\mathrm{OMe}$ OMe $\mathrm{H}$

7: $\mathrm{H} \quad \mathrm{O}-\mathrm{CH}_{2}-\mathrm{O} \quad \mathrm{H}$ OMe OMe OMe $\mathrm{H}$

8: $\mathrm{H} \quad \mathrm{O}-\mathrm{CH}_{2}-\mathrm{O} \quad \mathrm{H} \quad \mathrm{OH} \quad \mathrm{OMe}$ OMe $\mathrm{H}$

9: $\begin{array}{lllllllll}\mathrm{H} & \mathrm{H} & \mathrm{H} & \mathrm{H} & \mathrm{OH} & \mathrm{OMe} & \mathrm{OMe} & \mathrm{H}\end{array}$

10: $\mathrm{H} \quad \mathrm{O}-\mathrm{CH}_{2}-\mathrm{O} \quad \mathrm{H}$ OMe $\mathrm{H}$ OMe $\mathrm{H}$

12: $\mathrm{OMe} \mathrm{OMe}$ OMe $\mathrm{H}$ OMe $\mathrm{H}$ OMe $\mathrm{H}$

13: $\mathrm{H}$ OMe OMe $\mathrm{H}$ OMe OMe OMe $\mathrm{H}$

14: $\mathrm{H}$ OMe $\mathrm{H} \quad \mathrm{H}$ OMe $\mathrm{OMe}$ OMe $\mathrm{OMe}$

15: $\mathrm{OMe} \mathrm{OMe} \mathrm{OMe} \mathrm{OMe} \mathrm{OMe} \mathrm{OMe} \mathrm{OMe} \mathrm{H}$

16: $\mathrm{OMe} \mathrm{OMe} \mathrm{OMe} \mathrm{OMe} \mathrm{OMe} \mathrm{H}$ OMe $\mathrm{OMe}$<smiles>COc1cc(O)c(C(=O)/C=C/c2cc(OC)c(OC)c(OC)c2)c2c1C=CC(C)(C)O2</smiles>

11<smiles>COc1ccc(-c2coc3cc(O)c(OC)cc3c2=O)cc1</smiles>

17<smiles>COc1c(C(=O)c2ccccc2)oc2c1ccc1occc12</smiles>

18 
Thus, clearly isoflavonoids and auronoids deserve more attention as glyceraldehyde-3-phosphate dehydrogenaseinhibitors. Highly oxygenated flavones appear to possess the structural requirements for inhibiting trypanosomal GAPDH. However, to develop an effective blocking agent from the natural product lead compounds, it is necessary to determine as precisely as possible, how the tested compounds occupy the active site and at the same time how they make specific interactions with the amino acids of the target enzyme. Therefore, we still have not enough experimental evidence for developing a quantitative understanding of the structural basis of the specificity in the catalytic-site-activity relationships among flavonoids and the enzyme GAPDH.

\section{Experimental}

\section{General}

NMR on a Bruker DRX 400, with TMS as internal standard. HSQC, Heteronuclear Single Quantum Coherence; ESI-MS/MS, low resolution on a triple quadrupole Micromass Quattro LC instrument, equipped with a "Z-spray" ion source; R-HPLC, Recycling HighPerformance Liquid Chromatography on a model Shimadzu LC-6AD; detection (Shimadzu SPD-6AV), UV.

\section{Plant material}

Neoraputia paraensis was collected in Uruçuca, Bahia, Brazil, and a voucher (SPF 81-316) is deposited in the Herbarium of Instituto de Biociências, USP, São Paulo.

\section{Isolation of compounds}

Ground stems (2700 g) and leaves (409 g) of Neoraputia paraensis were extracted with $n$-hexane, then $\mathrm{CH}_{2} \mathrm{Cl}_{2}$ and finally with $\mathrm{MeOH}$. Only the concentrated extracts containing alkaloids, which were detected by the characteristic color with Dragendorff's reagent on thinlayer chromatography plates, were worked. Fractions were monitored by ${ }^{1} \mathrm{H}$ NMR $(200 \mathrm{MHz})$ and ESI-MS/MS and were examined only those which showed features of anthranilate alkaloids and flavonoids absent in the previous investigations.

The concentrated $\mathrm{CH}_{2} \mathrm{Cl}_{2}$ extract from stem was subjected to column chromatography over silica gel. Elution with a $n$-hexane- $\mathrm{CH}_{2} \mathrm{Cl}_{2}-\mathrm{MeOH}$ (1:1:0.2) afforded 16 fractions. Fraction 4 was flash chromatographed on silica gel, eluting with $\mathrm{CH}_{2} \mathrm{Cl}_{2}$-EtOAc gradient affording $\mathbf{1}$ $(10 \mathrm{mg})$. The concentrated $\mathrm{MeOH}$ extract was partitioned into $\mathrm{CH}_{2} \mathrm{Cl}_{2}$, EtOAc and n-BuOH-soluble fractions. The concentrated $\mathrm{CH}_{2} \mathrm{Cl}_{2}$-soluble fraction was subjected to column chromatography over silanized silica elution with $\mathrm{MeOH}-\mathrm{H}_{2} \mathrm{O}$ (1:1) afforded 10 fractions. Fraction 8 was flash chromatographed on silica gel, eluting with $\mathrm{CH}_{2} \mathrm{Cl}_{2}-\mathrm{MeOH}$ gradient affording 2 fractions. Fraction 1 was twice flash chromatographed on silica gel, eluting with $\mathrm{CH}_{2} \mathrm{Cl}_{2}$ EtOAc-MeOH (5:0.4:0.4) and finally with $\mathrm{CH}_{2} \mathrm{Cl}_{2}$-EtOAc$\mathrm{MeOH}$ (4.6: 0.6:0.4) affording skimmianine $(3 \mathrm{mg})$. Fraction 2 was purified by R-HPLC (the column used was a Shim-pack Prep-Sil (H), $250 \mathrm{~mm} \mathrm{X} 20 \mathrm{~mm}, 5 \mathrm{~mm}$ particle size, $100 \AA$ pore diameter; eluant: $\mathrm{CH}_{2} \mathrm{Cl}_{2}-\mathrm{MeOH}$ (99:1); flow rate: $4.0 \mathrm{~mL} \mathrm{~min}^{-1}$ ) (detection $\mathrm{UV}, \lambda 254 \mathrm{~nm}$ ) to give 2 (second peak, $1.2 \mathrm{mg}$ ) and dictamnine (first peak, $1.0 \mathrm{mg}$ ), after four cycles of $80 \mathrm{~min}$.

The concentrated $n$-hexane extract of the leaves was four times flash chromatographed on silica gel, eluting with $n$-hexane- $\mathrm{CH}_{2} \mathrm{Cl}_{2}-\mathrm{MeOH}$ gradient, $n$-hexane-EtOAc$\mathrm{MeOH}$ gradient, $n$-hexane-EtOAc gradient, and finally with silica gel and Florisil (1:1) eluting with $\mathrm{CH}_{2} \mathrm{Cl}_{2}$-EtOAc gradient affording 4 (20 mg).

The concentrated $\mathrm{CH}_{2} \mathrm{Cl}_{2}$ extract was twice flash chromatographed on silica gel, eluting with $\mathrm{CH}_{2} \mathrm{Cl}_{2}$ EtOAc-MeOH gradient and finally with $\mathrm{CH}_{2} \mathrm{Cl}_{2}$-EtOAc gradient affording 4 fractions. Fraction 1 was purified by R-HPLC (the column used was a Shodex Asahipack GS-

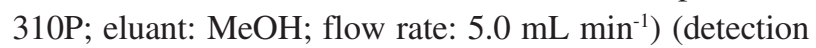
$\mathrm{UV}, \lambda 240 \mathrm{~nm}$ ) to give 8 (second peak, $2.7 \mathrm{mg}$ ), after three cycles of $60 \mathrm{~min}$. Fractions 2, 3 and 4 also were purified by R-HPLC (as above; flow rate: $6.0 \mathrm{~mL} \mathrm{~min}-1$ ) to give $\mathbf{5}$ (second peak, $5.0 \mathrm{mg}$ ), 6 (second peak, $4.0 \mathrm{mg}$ ) and 7 (second peak, $3.0 \mathrm{mg}$ ) after three cycles of $60 \mathrm{~min}$, respectively.

5-Hydroxy-3',4'-methylenedioxy-6,7-dimethoxyflavone (8). Yellow powder; ${ }^{1} \mathrm{H}$ NMR ( $400 \mathrm{MHz}, \mathrm{CDCl}_{3}$ ): see Table 2; ${ }^{13} \mathrm{C}$ NMR (100 MHz, $\mathrm{CDCl}_{3}$ ): see Table 2; ESI-MS/MS $\mathrm{m} / \mathrm{z}$ (rel. int.): $342[\mathrm{M}]^{+.}$(50), 181 (100): associated with retro-Diels-Alder cleavage of C-ring minus Me, 146 (40): associated with retro-Diels-Alder cleavage of C-ring.

Preparation and purification of recombinant T. cruzi GAPDH

TcGAPDH was overexpressed and purified as reported by Souza et al..$^{9}$ It is maintained in the Crystallography Laboratory of the University of São Paulo, São Carlos, SP, Brazil.

\section{T. cruzi GAPDH-activity}

TcGAPDH activity was determined according to a 
modification of a previously reported procedure. ${ }^{23}$ Reduced NADH was measured spectrophotometrically at $340 \mathrm{~nm}$ at 30 s interval. The reaction medium was $50 \mathrm{mmol} \mathrm{L}^{-1}$ Tris$\mathrm{HCl} \mathrm{pH} 8.6$ buffer, 1 mmol L ${ }^{-1}$ EDTA, $1 \mathrm{mmol} \mathrm{L}^{-1} \beta$ mercapto-ethanol, $30 \mathrm{mmol} \mathrm{L}{ }^{-1} \mathrm{Na}_{2} \mathrm{HAsO}_{4} 2.5 \mathrm{mmol} \mathrm{L}^{-1}$ $\mathrm{NAD}^{+}, 0.3 \mathrm{mmol} \mathrm{L}^{-1}$ glyceraldehyde-3-phosphate and 4-9 mg protein, in a total volume of $1000 \mu \mathrm{L}$. The reaction was initiated by the addition of enzyme.

The specific activity (unit $=\mathrm{U}$ ) of the enzyme was calculated as:

$\left(\mathrm{U} \mathrm{mg}^{-1}\right)=\{(\Delta$ absorbance/ $\Delta \mathrm{t}) \mathrm{x}$ volume of cell $\} / 6.22 \mathrm{x}$ volume of enzyme $x$ [ enzyme]

where $\Delta \mathrm{t}=0.5 \mathrm{~min}$; volume of cell $=1.00 \mathrm{~mL} ;{ }^{\varepsilon} \mathrm{NADH}=$ $6.22\left(\mathrm{mmol} \mathrm{L}^{-1}\right)^{-1} \mathrm{~cm}^{-1}$; volume of enzyme $=0.005 \mathrm{~mL}$; [enzyme] concentration of enzyme in $\mathrm{mg} \mathrm{mL}^{-1}$.

\section{T. cruzi GAPDH-inhibitory activity}

The inhibitory activity was recorded using the reaction medium as above, in a total volume of $1000 \mu \mathrm{L}$. Absorbance was read at $340 \mathrm{~nm}$ at 30 s interval. Flavonoids were tested at 50 and $100 \mu \mathrm{g} \mathrm{mL}^{-1}$ in $10 \%$ DMSO using $5 \mu \mathrm{L}$ of GAPDH at $0.90 \mathrm{mg} \mathrm{mL}^{-1}$.

In each case, a blank experiment was performed with $10 \%$ DMSO in the reaction medium and was used as the positive control. The specific activity of TcGAPDH was not significantly affected by the presence of $10 \%$ DMSO.

Data were means of 3 repetitions and values as percent of control were used as follows:

$\%$ inhibitory activity $=\left\{\left(\mathrm{U} \mathrm{mg}^{-1}\right.\right.$ control $-\mathrm{U} \mathrm{mg}^{-1}$ compound)/U mg-1 control\} $\times 100$

Enzymatic inhibition studies have been carried out in the Crystallography Laboratory of the University of São Paulo, São Carlos, SP, Brazil.

Some of the potentially active substances, as flavones $\mathbf{6}$ and $\mathbf{8}$, can not be assayed with the standard procedure described here, due to problems of solubility in the reaction buffer and absorption of light close to the wavelength used to observe the reaction course $(340 \mathrm{~nm})$. To overcome these limitations an alternative technique is being developed, based on calorimetric measurements, similar to procedures adopted with other enzymes. ${ }^{24}$

\section{Acknowledgements}

The authors thank Conselho Nacional de Desenvolvimento Científico e Tecnológico (CNPq), Fundação de
Amparo à Pesquisa do Estado de São Paulo (FAPESP), Coordenação de Aperfeiçoamento de Pessoal de Ensino Superior (CAPES). G.O. is an International Scholar of the Howard Hughes Medical Institute.

\section{References}

1. Emmerich, M.; Rodriguesia 1987, 45, 223.

2. Arruda, A. C.; Vieira, P. C.; Silva, M. F. das G. F. da; Fernandes, J. B.; Francisco, R. H. P.; Rodrigues, A. M. G. D.; Lechat, J. R.; Phytochemistry 1991, 30, 3157.

3. Arruda, A. C.; Vieira, P. C.; Fernandes, J. B.; Silva; M. F. das G. F. da; J. Braz. Chem. Soc. 1993, 4, 80.

4. Passador, E. A. P.; Silva, M. F. das G. F. da; Rodrigues Fo., E.; Fernandes, J.B.; Vieira, P. C.; Pirani, J. R.; Phytochemistry 1997, 45, 1533.

5. Tomazela, D. M.; Pupo, M. T.; Passador, E. A. P; Silva, M. F. das G. F. da; Vieira, P. C.; Fernandes, J. B.; Rodrigues Fo, E.; Oliva, G.; Pirani, J. R.; Phytochemistry 2000, 55, 643.

6. Souza, J. P. I.; Arruda, A. C.; Arruda, M. S. P.; Fitoterapia 1995, LXVI, 465.

7. Souza, J. P. I.; Arruda, A. C.; Muñoz, G. D.; Arruda, M. S. P.; Müller, A. H.; Phytochemistry 1999, 52, 1705.

8. Silva, M. F. das G. F. da; Gottlieb, O. R.; Ehrendorfer, F.; $P l$. Syst. Evol. 1988. 16, 97.

9. Souza, D. H. F.; Garratt, R. C.; Araújo, A. P. U.; Guimarães, B. G.; Jesus, W. D. P.; Michels, P. A. M.; Hannaert, V.; Oliva, G.; Febs Lett. 1998, 424, 131.

10. Rozsa, Z.; Rabik, M.; Szendrei, K.; Kalman, A.; Argay, G.; Pelczer, I.; Aynechi, M.; Mester, I.; Reisch, J.; Phytochemistry 1986, 25, 2005.

11. Ahond, A.; Picot, F.; Potier, P.; Poupat, C.; Sévenet, T.; Phytochemistry 1978, 17, 177.

12. Auzi, A. A.; Hartley, T. G.; Waterman, P. G.; Biochem. Syst. Ecol. 1997, 25, 611.

13. Brown, N. M. D.; Grundon, M. F.; Harrison, D. M.; Surgenor, S. A.; Tetrahedron 1980, 36, 3579.

14. Pusset, J.; Lopez, J. L.; Pais, M.; Neirabeyeh, M. A.; Veillon, JM.; Planta Med. 1991, 57, 153.

15. Ali, M. S.; Pervez, M. K.; Saleem, M.; Tareen, R. B.; Phytochemistry 2001, 57, 1277.

16. Horie, T.; Tominaga, H.; Kawamura, Y.; Phytochemistry, 1993, 32, 1076.

17. Chen, J.; Montanari, A. M.; Widmer, W. W.; J. Agric. Food Chem. 1997, 45, 364.

18. Agrawal, P. K.; Carbon-13 NMR of Flavonoids, Elsevier: New York, 1989.

19. Ferracin, R. J.; Silva, M. F. das G. F. da; Fernandes, J.B; Vieira, P.C.; Phytochemistry 1998, 47, 393.

20. Garcia, C. F.; PhD Thesis (in progress), Universidade Federal de São Carlos, Brazil, 2002. 
21. Sannomiya, M.; Ph.D. Thesis, Universidade Estadual de Campinas, SP, Brazil, 2001.

22. Vieira, P. C.; Mafezoli, J.; Pupo, M. T.; Fernandes, J. B.; Silva, M. F. das G. F. da; Albuquerque, S.; Oliva, G.; Pavão, F.; Pure Appl. Chem. 2001, 73, 617.
23. Barbosa, V. M.; Nakano, M.; Comp. Biochem. Physiol. 1987, $88 B, 563$

24. Aitken S. M.; Turnbull J. L.; Percival M. D.; English A. M.; Biochemistry 2001, 40,13980.

Received: March 28, 2002

Published on the web: February 28, 2003

FAPESP helped in meeting the publication costs of this article. 